\title{
Optimization of Information Systems Academic Schedule Based on Mobile Application Using WEB Service Bridge
}

\author{
Mohammad Ridwan ${ }^{1}$, Muhammad Khoirul Anam² \\ \{mridwan@unis.ac.id ${ }^{1}$, mkanam@unis.ac.id² \\ Informatics Engineering Study Program, Islamic University of Sheikh Yusuf Tangerang, St. Maulana Yusuf Tangerang \\ 15118, Indonesia $^{1,2}$
}

\begin{abstract}
Academic information systems are built to provide convenience to users in campus academic activities online. SINA system (Academic Information System) at Islamic University Sheikh Yusuf has been able to provide excellent service to students, lecturers, and university employees, but there are still some who need further development in order to realize the optimal information presented. It was recorded that only $16 \%$ of the total active students were actively logged into SINA, this was because millennial students prioritized viewing mobile applications rather than websites, especially those that smelled of social media. With less optimal information received by the students of Syekh Yusuf Islamic University today, especially information on class schedules. Therefore, it will be made a mobile-based application that is expected to be able to convey information to students in real time.
\end{abstract}

Keywords: academic schedule, lecture schedule, m-schedule, mobile app, mobile schedule.

\section{Introduction}

One technology that is almost always in our lives is web and mobile technology. In today's urban life, especially millennials, web and mobile technology have become important aspects. Coupled with the increasingly wides pread social media and applications for exchanging mes sages, everyone can communicate with his friends anytime and anywhere.

Academic Sys temat Is lamic University Sheikh Yusuf(UNIS) has found his identity after developing the latest academic systemcalled SINA (Academic Information System), the system has been able to provide excellent service to students, lecturers, and university employees, but there are still some who need development ag ain in order to realize the optimal information presented, one of them in the aspect of mobility is the Mobile System. Currently Android or iOS mobile phones are already entrenched in the world of students including UNIS students. It was recorded that only $16 \%$ of the total active students were actively logged into SINA, this was because millennials students prioritized seeing mobile applications rather than websites, especially those that smelled of social media.

With the lack of optimal information received by UNIS students now and especially information on class schedules, there needs to be new breakthroughs and development using the latest technology to solve the problem. One of them is using camouflage techniques. The camouflage technique here intends to resemble the SINA system into a mobile system, which is where the habits of students are located.

So researchers try to research and provide solutions by making an applic ation or mobile-based system that is expected to be able to convey information to students in real time. in this design the researcher uses web service as its bridge and AJAX technology as its generator service. Web Service is one of the back layer information technology capable of bridging two or more different technology platforms, while AJAX is a development technology fromjava script that is able to automatically call or wake up the system. Based on the description above, in this study we would like to conduct research with the topic of Optimizing Lecture Schedule Information on Mobile Application Based on Mobile Application Using the Web Service Bridge .

\section{Re lated Research}

In a previous study entitled Designing Mobile Applications for Notification of Android-Based Lecture Schedules (Case Study: Stmik Provisi Semarang), the main database of applications has not been combined with the database that already exists in STMIK ProVisiSemarang. In this study, themain database of applications will be 
combined with the database found at Syekh YusufTangerang Islamic University. The purpose of this study is to create an application that is able to simultaneously connect data and information in the UNIS Academic System into the Mobile Application System. The Mobile Application Systemis able to show Lecture Schedule data and information as well as information on the UNIS Academic System to students and also as a reminder of the schedule for both the schedule of the day, tomorrow, tomorrow and tomorrow and the overall schedule according to the academic period.

\section{Method}

\subsection{Research Method}

Researchers use Research and Development methods or Research and Development (R \& D). According to Surya (Dharma, 2008) is a strategy or research method that is powerful enough to improve practice. What is meant by Research and Development or Research and Development (R\&D) is a series of processes or steps in order to develop a new product or perfect an existing product so that it can be justified. These products are not always shaped objects or hard ware, such as books, modules, learning aids in the class room or in the laboratory, but can also be software, such as computer programs for processing data, learning in clas s, library or laboratory, or models of education, learning, training, guidance, evaluation, management systems.

The initial stage of this research is to develop an application, then develop according to the needs and circumstances in the field. Research and Development methods or Research and Development (R \& D) will continue to run and develop according to the needs and changes in the field.

\subsection{System Development Method}

Extreme Programming (XP) is one of the most frequently used methodologies in Agile Development. This method requires more collaboration with customers and involves customers in the software development cycle than other structured processes [9]. One of XP's goals is to reduce the cost of possible software changes, with code carried out at each step being an indicator of project progress [3].

Stage in the development cycle of the Extreme Programming method [10]:

- Exploration Stage: At this stage, the user tells all the needs that will be involved in the software.

- Planning Phase: This stage focuses on setting the priority of the requirements provided by the user and setting the schedule for making software.

- Iteration Stage to Releas e: This stage focuses on creating a prototype and each progress produced will be discussed with the user. At this stage, the results of feedback by users will be evaluated and used for software improvements and then release new versions of software and of course according to user requirements.

- Productionizing Stage: This stage is the stage of making and releasing software that will be tested by the user. Previously it was checked again to be adjusted to the requirements of the user.

\section{Result \& Discussion}

\subsection{Business Modeling}

In designing this system, researchers need to use additional methods to help synchronize data simultaneously, among others :

- Parsing Data Method, dataparsing is used when the system wants to exchange data from one platform to another. This method has a different scheme between one platformand another platform. In this study the base platform used is an Android Mobile App where data parsing methods use the Volley function.

- Web Service Method, Web Service is a media created as a provider of cloud data and as an object of data exchange (Parsing Data). Web Services must be connected directly to the Database Management System (DBMS) to be able to send data manipulation and search commands so that they can then be presented and utilized by Parsing Data Systems. To make it neces sary to have additional methods with a websitebased platform.

- Web Service Method, Web Service is a media created as a provider of cloud data and as an object of data exchange (Parsing Data). Web Services must be connected directly to the Database Management System (DBMS) to be able to send data manipulation and search commands so that they can then be presented and utilized by Parsing Data Systems. To make it neces sary to have additional methods with a websitebased platform.

From the description above, the researcher analyzed the data and processes using several methods described above, and visualized the analysis into the Modeling Business. This Modeling Business describes general and 
technical processes that will be implemented into Design Modeling by emphasizing user and systemneeds. Next is the Modeling Business that has been designed by the Researcher.

\section{UNIS Integrated Lecture Schedule Mobile Application}

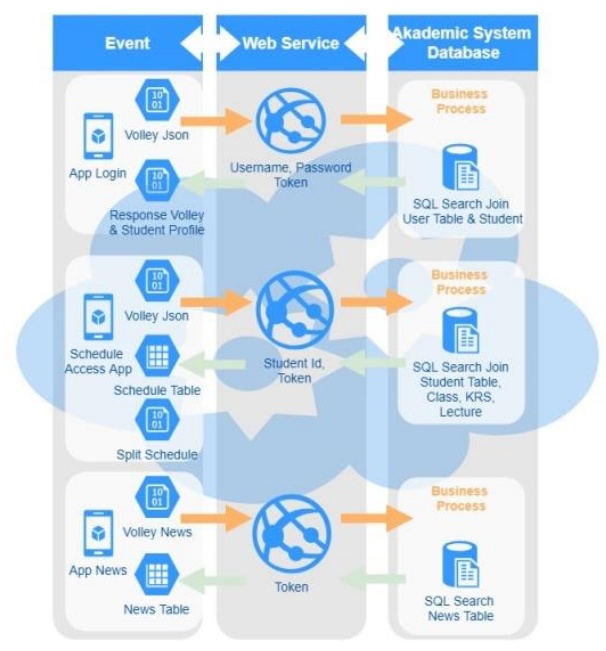

Figure 1. UNIS Integrated Lecture Schedule Mobile Aplication

From the picture above, explain about 3 (three) main events, namely :

- App Login

This activity starts from the mobile App sending a volley request to the web service by bringing a username, password, and token and will be received by the web service which will then be created a validation login search query before being sent to the UNIS Academic System Database to execute the query. After that, the new web service will dis play theresults as a response that will be captured by the Volley function and will be arranged according to the needs of student logins and profiles.

- Schedule Access App

This activity starts from the mobile App sending a volley request to the web service by bringing the student NIM and token and will be received by the web service which will then be made a schedule data search query before being sent to the UNIS Academic SystemDatabase to execute the query. After that, the new web service will display the results as a res ponse that will be captured by Volley's functions and will be arranged according to needs, including today's schedule, tomorrow's schedule, day-to-day schedule, and all schedules.

- App News

This activity starts from the mobile App sending a volley request to the web service by bringing a token and will be received by the web service which will then be made a search query news data before being sent to the UNIS Academic SystemDatabase to execute the query. After that, the new web service will display the results as a response that will be captured by the Volley function and will be arranged according to system requirements.

\subsection{Design Modeling}

Furthermore, in designing this systemthere are stages of modeling design, the researcher divides the two stages in this design phase by including the main processes according to the modeling business. These two stages are among others :

- Web Design Service

In designing this web service, researchers create functions that are simple and able to receive data from the Client App and will send a response back, Below is a Table of Request (Request) and Response (Response) web service: 
Table 1. Design Web Service

\begin{tabular}{|c|c|c|c|c|}
\hline No & Fungsi & Query & Request & Response \\
\hline 1 & $\begin{array}{l}\text { Loginmob } \\
\text { ile() }\end{array}$ & $\begin{array}{l}\text { Select us ername, m.nama, m.tmplahir as } \\
\text { tmplhr, m.tgllahir as tgllhr, m.alamat as } \\
\text { alamat,m.hp as hp, m.email as email, } \\
\text { m.jk as jk from us eru join mahasis wa m } \\
\text { on u.us ername=m.nim where us ername } \\
=\text { 'username' and password ='password' }\end{array}$ & $\begin{array}{l}\text { Username, } \\
\text { pass word, } \\
\text { token }\end{array}$ & $\begin{array}{l}\text { us ername, nama, tmplhr, } \\
\text { tgllhr, alamat,hp, email,jk }\end{array}$ \\
\hline 2 & $\begin{array}{l}\text { Jadwalmo } \\
\text { bile( })\end{array}$ & $\begin{array}{c}\text { Select } \\
\text { k.namakelas,m.namamk,m.sks mk,p.idru } \\
\text { ang,p.tgljadwal,p.waktumulai,p.waktuse } \\
\text { lesai,w.nama,w.nip fromkelas k join krs } \\
\text { kr on kr.idkelas=k.idkelas join } \\
\text { matakuliah m on (m.idmk=k.idmk and } \\
\text { m.idkurikulum=k.idkurikulum) join } \\
\text { perkuliahan p on p.idkelas=k.idkelas } \\
\text { join mengajar j on j.idkelas=k.idkelas } \\
\text { join pegawai w on w.nip=j.nip where } \\
\text { kr.nim='username' and } \\
\text { p.statusperkuliahan='0' and } \\
\text { k.idperiode='periode' and tgljadwal is } \\
\text { NOT NULL order by } \\
\text { p.tgljadwal,p.waktumulai ASC }\end{array}$ & Nim, token & $\begin{array}{c}\text { namakelas, namamk, sksmk, } \\
\text { idruang, tgljadwal, } \\
\text { waktumulai,waktuseles ai,na } \\
\text { ma, nip }\end{array}$ \\
\hline 3 & $\begin{array}{l}\text { Jadwalberi } \\
\operatorname{ta}()\end{array}$ & $\begin{array}{l}\text { select } * \text { from berita order by idberita } \\
\text { DESC }\end{array}$ & token & All Field \\
\hline
\end{tabular}

- Design the Mobile Client App

Below is a design template and App page from the login process to profile pages, schedules and news. Here's the design :

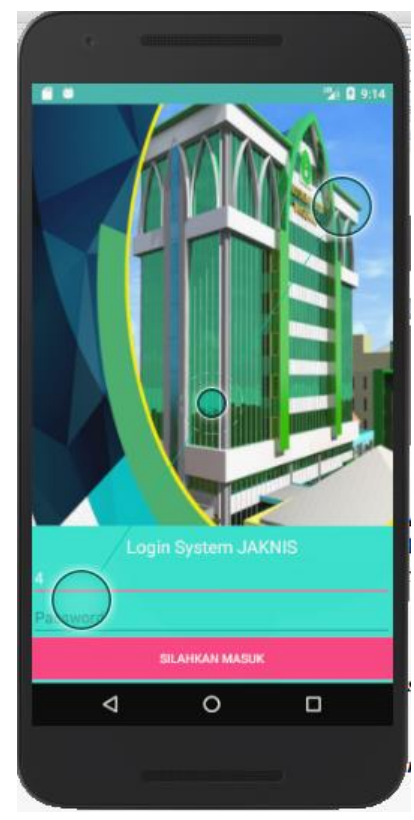

Figure 2. Design Login Page

This page will interact directly with the academic systemdatabase to get validation whether the username and password entered matches the student data in the academic system. 


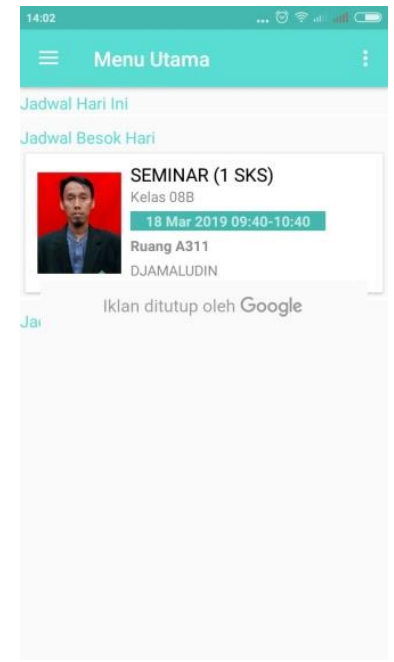

Figure 3. Main Page Design

While for the page above is the main page of the system that displays a summary of tod ay's schedule, tomorrow and also the day after tomorrow.

For the picture Figure 4 and Figure 5 below is the navigation menu and also additional system service settings.

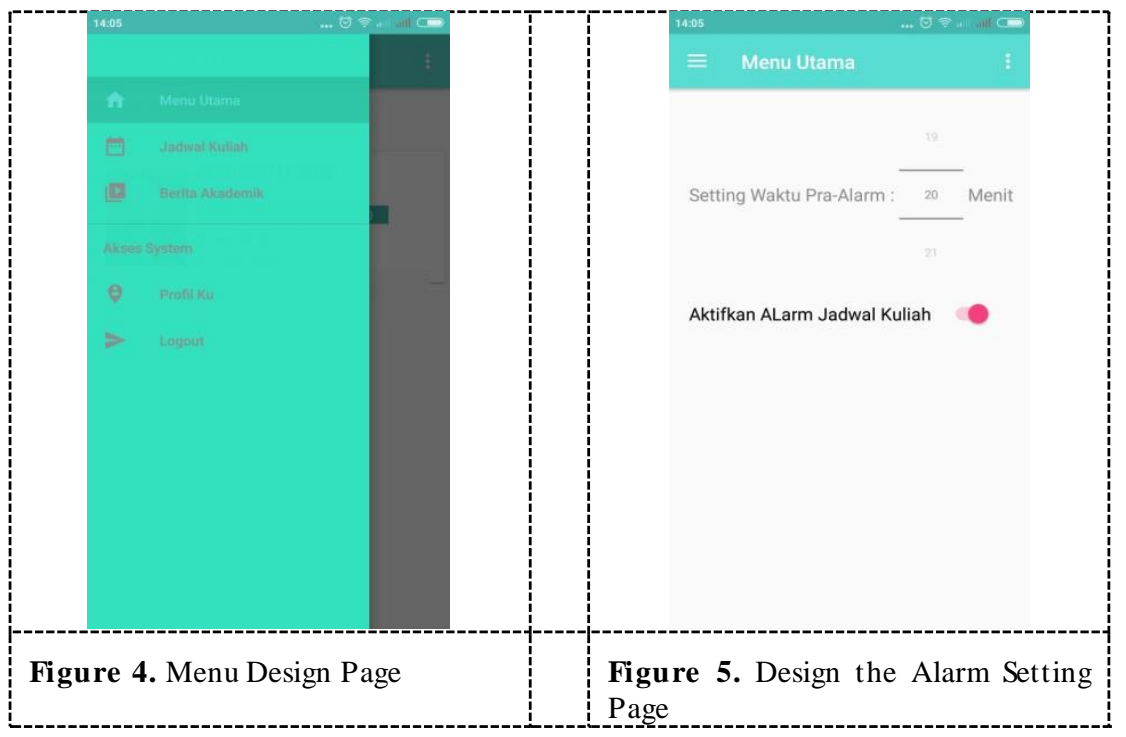

While the page below shows the entire lecture schedule that adjusts to the academic period. 

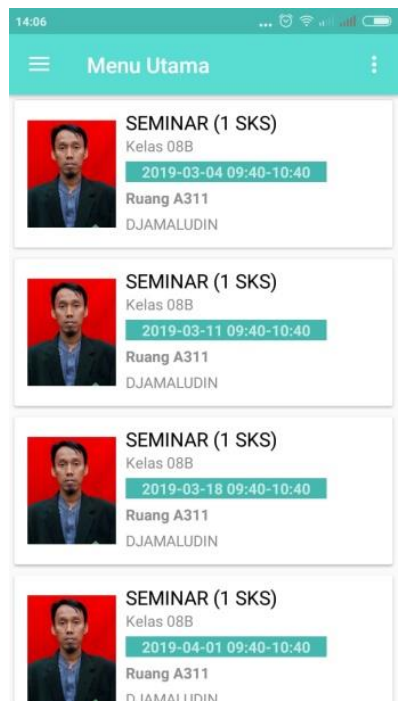

Figure 6. Design All Schedule Pages

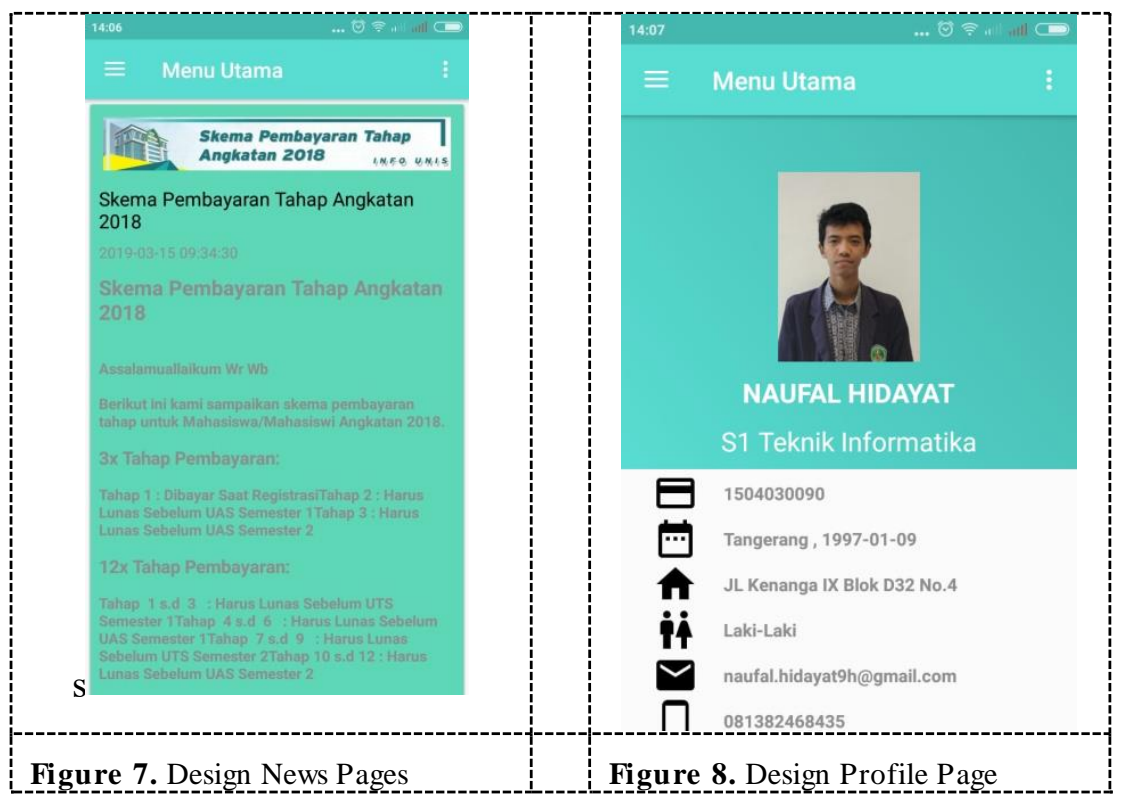

Figure. 7 and Figure. 8 is each displaying an internal academic system news and also the profile data of the student concerned.

\subsection{User Acceptance Test}

The researcher used the UAT (User Acceptancet Test) testing method which prioritizes satisfaction and approval of Systemusers, users here are active students.

The new System Test Results can be seen in the table below:

Table 2. Results of User Acceptance Test

\begin{tabular}{ccccc}
\hline No & Proses & Accepment & Revisi & Status Revisi \\
\hline 1 & Login & V & SINA Integration & Finish \\
2 & Main Page & V & SINA Integration & Finish
\end{tabular}




\begin{tabular}{ccccc}
3 & Schedule Page & V & Data Filter & Finish \\
4 & News & V & - & Finish \\
5 & Profil & V & - & Finish \\
\hline
\end{tabular}

From the results of the systemtest / trial above, it can be concluded that the systemhas fulfilled the needs of users / students, to improve the mobile app systemthe class schedule will be carried out further research.

\section{Conclusion}

Making and developing Mobile Application Optimization Information on Academic Schedule Academic Systems Using the Web Service Bridge was successfully implemented by integrating into the UNIS academic system. The development of this research is able to be completed by simultaneously connecting data and information in the UNIS Academic Sys teminto the Mobile Application System. The Mobile Application System is able to show Lecture Schedule data and information as well as information on the UNIS Academic System to students and also as a reminder of the schedule for both the schedule of the day, tomorrow, tomorrow and tomorrow and the overall schedule according to the academic period. Future research needs to be made for lecture schedules and attendance processes in lectures, for further development will focus more on the lecturers' side in the theme of the lecture schedule.

\section{References}

[1] Agungsr. (2011). Sistem informasi. Sistem Informasi, 1-13. Retrieved from http://agungsr.staff.gunadarma.ac.id/Downloads/files/3412/Konsep+SI.pdf

[2] Agungsr. (2011). Sistem informasi. Sistem Informasi, 1-13. Retrieved from http://agungsr.staff.gunadarma.ac.id/Downloads/files/3412/Konsep+SI.pdf

[3] 1. Borth, M.R. \& Shishido, H. Y. A Comparative Analy sis of Two Software Development Methodologies: Rational Unified Process and Extreme Programming. Rev. Vértices 15, 143-157 (2014). https://doi.org/10.5935/1809-2667.20130035

[4] Klein, A., Mannweiler, C., Schneider, J., \& Schotten, H. D. (2010). Access schemes for mobile cloud computing. In Proceedings - IEEE International Conference on Mobile Data Management (pp. 387-392). https://doi.org/10.1109/MDM.2010.79

[5] Ramadhan, T., \& Utomo, V. (2014). Rancang Bangun Aplikasi Mobile Untuk Notifikasi Jadwal Kuliah Berbas is Android (Studi Kasus: Stmik Provisi Semarang). Jurnal Teknologi Informasi Dan Komunikasi, 5(2), 47-55. https://doi.org/10.1234/JTIK.V5I2.93

[6] Satria Darmawangsa, N., \& Studi Ilmu Komputer, P. (2011). Rancang Bangun Web Service Untuk Penjualan Tiket Bus Damri. Jurnal Informatika Mulawarman, 6(2), 54-63.

[7] Kasman, Akhmad Dharma. 2015. Trik Kolaborasi ANDROID dengan PHP dan MySQL. Yogyakarta. Lokomedia.

[8] Json Org. JSON [Online]. Url: http://json.org/json-id.html. [20 November 2016]

[9] Mohammadi, S. et. al. (2009). Challenges of user Involvement in Extreme Programming projects. International Journal of Software Engineering and Its Applications

[10] Awad, M. A. (2005). A Comparis on between Agile and TraditionalSoftware Development Methodologies . The University of Western Australia. 